\title{
REPRODUÇÃO ELEITORAL, ESPECIALIZAÇÃO OU CARTELIZAÇÃO LEGISLATIVA? A COMISSÃO DE MINAS E ENERGIA DA CÂMARA DOS DEPUTADOS EM PAUTA
}

\author{
Clemar Pereira Gonçalves da Silva Côrtes*
}

Resumo: O artigo avalia a dinâmica da Comissão de Minas e Energia da Câmara dos Deputados, entre 2003 e 2006, sob o enfoque das Teorias do Legislativo e do Agenda Setting, tendo-se verificado dominância das perspectivas distributivista e partidária sobre a informacional, visto que os trabalhos no âmbito do órgão nortearam-se por preferências do Poder Executivo e que a motivação de seus membros centrou-se na reeleição.

Palavras-chave: audiência pública; comissões; especialização; mídia; reeleição.

\begin{abstract}
The paper evaluates the dynamics of the Committee of Mines and Energy of the Chamber of Deputies, from 2003 to 2006, under de approach of the Theories of the Legislative and of the Agenda Setting. It has been verified that the distributivist and the partisan theories prevailed on the informacional, as the preferences of the Executive guided the work done and the members' motivation was centered in the re-election.
\end{abstract}

Keywords: agenda setting; committees; expertise; public hearing; re-election.

\section{Introdução}

O estudo do funcionamento das instituições políticas brasileiras tem estimulado investigações acadêmicas na busca de tradução para os processos de formulação e de implementação das políticas públicas nacionais contemporâneas. No sentido de cooperar com o debate, este artigo discorre sobre parte da dinâmica legislativa da Comissão de Minas e Energia da Câmara dos Deputados (CME), comissão permanente de enfoque predominantemente econômico, cujos trabalhos assumiram vertiginosa importância ante crescentes discussões sobre temáticas de relevância nacional e internacional, mas cujas deliberações acerca de projetos de

\footnotetext{
* Graduada em Ciências Econômicas (UniDF) e em Direito (UniCeub); Especialista em Instituições e Processos Políticos do Legislativo (Cefor); Analista Legislativa da Câmara dos Deputados (clemar.cortes@ camara.gov.br).
} 
lei não constituíram seu objeto primeiro no curso da $52^{\mathrm{a}}$ Legislatura. É o que se pode observar nos quadros abaixos:

Quadro n. ${ }^{\circ} 1$ - Quantitativo de reuniões realizadas e de proposições em trâmite e apreciadas no âmbito da CME

\begin{tabular}{lcccccc|c|}
\multicolumn{1}{c}{ CME } & $\mathbf{2 0 0 3}$ & $\mathbf{2 0 0 4}$ & $\mathbf{2 0 0 5}$ & $\mathbf{2 0 0 6}$ & Total \\
\hline Reuniões Informacionais & 22 & 11 & 7 & 8 & 48 \\
Reuniões Deliberativas & 26 & 19 & 25 & 14 & 84 \\
Projetos que tramitaram & 87 & 129 & 65 & 76 & 357 \\
Projetos votados & 18 & 30 & 18 & 30 & 96 \\
Requerimentos que tramitaram & 153 & 109 & 85 & 82 & 429 \\
Requerimentos votados & 137 & 88 & 58 & 60 & 343 \\
\hline
\end{tabular}

Fontes: Relatórios Anuais da CME e Sileg.

Quadro n. 2 - Quantitativo de requerimentos votados na CME

\begin{tabular}{|c|c|c|c|c|c|c|}
\hline $\begin{array}{c}\text { Requerimentos } \\
\text { Apreciados na } \\
\text { CME }\end{array}$ & 2003 & 2004 & 2005 & 2006 & Total & Tipo \\
\hline Audiência Pública & 43 & 34 & 21 & 28 & 126 & \multirow{8}{*}{$\begin{array}{c}198 \\
\text { requerimentos de } \\
\text { cunho informacional }\end{array}$} \\
\hline Auditoria & 1 & 0 & 0 & 1 & 2 & \\
\hline Convocação de Ministro & 0 & 0 & 0 & 0 & 0 & \\
\hline Comissão Geral & 0 & 1 & 0 & 0 & 1 & \\
\hline Grupo de Trabalho & 1 & 1 & 0 & 0 & 2 & \\
\hline Informação & 37 & 13 & 0 & 1 & 51 & \\
\hline Seminário & 9 & 1 & 2 & 2 & 14 & \\
\hline Sub-comissão & 1 & 1 & 0 & 0 & 2 & \\
\hline GF dos Ex-Presidentes & 1 & 0 & 0 & 0 & 1 & \multirow{7}{*}{$\begin{array}{c}145 \\
\text { outros }\end{array}$} \\
\hline Indicação & 1 & 2 & 0 & 0 & 3 & \\
\hline Moção de apoio & 0 & 2 & 0 & 0 & 2 & \\
\hline Viagem & 0 & 0 & 0 & 0 & 0 & \\
\hline Procedimentais $^{1}$ & 43 & 33 & 34 & 28 & 138 & \\
\hline Projeto de Resolução & 0 & 0 & 0 & 0 & 0 & \\
\hline Publicação & 0 & 0 & 1 & 0 & 1 & \\
\hline Total & 137 & 88 & 58 & 60 & 343 & 343 \\
\hline
\end{tabular}

Fontes: Relatórios Anuais da CME.

No curso de 84 reuniões deliberativas realizadas pela CME, entre 2003 e 2006, apenas 96 projetos foram alvo de deliberação, enquanto 343 requerimentos ${ }^{2}$ foram apreciados. Então, para cada 1,1428 projeto discutido e votado por reunião, em média, foram discutidos e votados 4,0833 requerimentos. Destaque-se o quantitativo deliberado de requerimentos de cunho informacional, isto é, de audiência pública, de seminário, de comissão geral, de convocação de ministro de estado, de grupo de trabalho, de auditoria e de informação ${ }^{3}$, que foi de 198 , e, em

\footnotetext{
${ }^{1}$ Entende-se por requerimentos procedimentais os protocolados no sentido de se obterem retirada de pauta ou de tramitação de proposição; preferência para votação; inclusão na Ordem do Dia para apreciação imediata; entre outras.

${ }^{2}$ Requerimentos são proposições de autoria parlamentar que solicitam determinada realização ou providência e que importam necessária aprovação da presidência ou do colegiado pertinente, conforme exigêncial regimental. Arts. 100 a 107 e 114 a 117 do Regimento Interno da Câmara dos Deputados (RICD).

${ }^{3}$ As modalidades de requerimento mencionados são consideradas de cunho informacional especialmente por que pretendem a aquisição de conhecimento que provenha da parte de outrem, sejam outros parlamentares, sejam representantes da sociedade civil, do Poder Executivo, do Tribunal de Contas da União ou entes judiciários.
} 
especial, o número de requerimentos de audiência pública, 126, números estes que isoladamente superaram o número de projetos de lei votados.

Pergunta-se: por que o volume de deliberações de projetos de lei foi superado pelo de deliberações de requerimentos de cunho informacional, na CME, na $52^{\mathrm{a}}$ Legislatura? Por que os membros da CME apresentaram quantitativo tão expressivo de requerimentos de cunho informacional nesse período? Este artigo pretende responder a essas indagações.

\section{Fundamentação Teórica}

Ao importar recursos teóricos oriundos da "nova economia da organização" (Weingast e Marshall, 1988), cientistas políticos norte-americanos, de vertente neo-institucionalista, fizeram uso de instrumentos da microeconomia na previsão do comportamento de atores políticos dentro do Congresso norte-americano, ao discorrer sobre mecanismos institucionais pelos quais um principal pode exercer controle sobre a atividade e a obediência de seus agentes (Pratt e Zeckhauser, 1991). Nesse sentido, houve absoluto consenso na identificação do agente, as comissões parlamentares ${ }^{4}$. A questão central tornou-se identificar o ator precípuo do processo legislativo, o denominado principal: se os deputados individualmente, se a maioria (o plenário da casa legislativa) ou se os partidos, cada hipótese atrelada a uma vertente teórica distinta.

David Mayhew (1974) assevera que toda a estrutura institucional interna do Congresso norte-americano foi modelada com vistas à reprodução eleitoral, e que as comissões constituem o principal fórum viabilizador desse objeto - tendo em vista seu monopólio de jurisdição sobre os respectivos campos temáticos - a partir de três estratégias adotadas pelos deputados: a da propaganda de suas ações no Congresso junto aos eleitores (credit claiming), em um esforço para passar uma imagem positiva e reivindicar créditos pela alocação de benefícios desagregados; a da distribuição de benefícios na forma de políticas públicas ou favores e vantagens a indivíduos (pork barrel/casework), motivada pela busca de reconhecimento, por meio da conferência de publicidade à reputação pessoal do congressista (advertising), no sentido de disseminar a crença de que sua atuação é capaz de atender aos anseios do eleitorado; e a da tomada de posição (position taking), por meio do anúncio público de julgamento sobre temática de interesse dos eleitores. Essa teoria, denominada Distributivista, considera as comissões agentes de distribuição.

A Teoria Informacional, por sua vez, entende que as comissões parlamentares representam fatores especializados de produção (Gilligan e Krehbiel, 1987; Krehbiel, 1991). Sob esta ótica, alguns parlamentares detêm mais conhecimento que outros acerca de matérias específicas - informação assimétrica - e tomam decisões sem dispor de certeza sobre o resultado

\footnotetext{
${ }^{4}$ As comissões parlamentares são órgãos integrantes do Parlamento, criados com o propósito de desconcentrar a competência institucional legislativa, por meio de delegação vertical ou hierárquica, também denominada interna corporis, consubstanciando especialização de parcela do Parlamento para o exercício da atividade legiferante.
} 
das políticas sobre as quais deliberam. Se, de um lado, percebe-se que a redução de incertezas é um bem coletivo, na medida em que a maioria se beneficia quando o maior número possível de parlamentares detém o maior grau de conhecimento possível, o que, por consequência, diminui o nível de incerteza; do outro lado, a existência de informação assimétrica dá lugar a sua utilização estratégica - especialistas têm a tendência de não dividir todo o seu conhecimento com seus pares e seus interesses particulares normalmente não se apresentam totalmente de acordo com os da maioria.

Já Cox e McCubbins (1993 e 1994), defensores da Teoria Partidária, consideram que os partidos, em especial o majoritário, encerram uma espécie de "cartel legislativo", que usurpa o poder do Congresso com vistas a criar regras que governem a estrutura e o processo legislativo. Em razão disso, o processo legislativo em geral, especialmente no âmbito do sistema de comissões, sujeitar-se-ia aos interesses do partido majoritário. Como este deteria todas as vantagens possíveis, os principais atores da parte predominante das transações mais importantes realizadas seriam seus membros, e os acordos centrais por ele firmados seriam facilitados pelas regras do cartel e vigiados por sua liderança. Sob essa perspectiva, o poder do presidente da casa legislativa e dos líderes partidários pode ser considerado superior ao das comissões, uma vez que estas, ao tomar decisões acerca de qualquer proposição, precisarão antecipar a ação dos atores no próximo estágio do processo legislativo (Limongi, 1994).

Embora as teorias do Legislativo mencionadas tenham sido criadas em oposição recíproca, urge conciliá-las para se avaliar o caso brasileiro, especialmente se considerado o fato de que o desenho institucional pátrio outorgou ao titular do Poder Executivo preponderância de iniciativa legislativa, em face de prerrogativas constitucionais insertas na Carta de 1988. Acrescente-se que, a partir de estudo pioneiro, Limongi e Figueiredo (1998) inferiram que praticamente tudo o que o Poder Executivo submete ao Legislativo é aprovado, sob o amparo de prerrogativas outorgadas por regras institucionais. As evidências revelaram a existência de apoio parlamentar em grau de maioria (em moldes semelhantes ao de sistemas parlamentaristas de governo) e a interdependência entre a preponderância legislativa do Poder Executivo, o padrão centralizado dos trabalhos legislativos (assegurado pelos regimentos internos das casas legislativas) e a disciplina partidária.

Ademais, é essencial considerar a formação da agenda pública pelos meios de comunicação de massa - o agenda-setting (Mccombs e Shaw, 1977), quando procedem à escolha dos temas que mobilizarão a opinião pública e que, consequentemente, influenciarão os tomadores de decisões públicas, sejam eles burocratas ou políticos. O agendamento do Poder Legislativo pelos meios de comunicação de massa revela o poder destes de influenciar os parlamentares na determinação das matérias que se sujeitarão à apreciação das casas legislativas, tendo em vista que os membros do Poder Legislativo buscam alcançar credibilidade junto aos grupos sociais que os elegem por meio dos mídia, no sentido de cooptar a opinião 
pública ${ }^{5}$. Verifica-se que as matérias de jornais locais são utilizadas nos pronunciamentos em razão de sua grande influência sobre o eleitorado respectivo, e que o que pauta o conteúdo das proposições legislativas denominadas requerimentos são acontecimentos midiáticos (Rodrigues, 2002).

\section{As Comissões Permanentes da Câmara dos Deputados e as regras institucionais}

A Câmara dos Deputados (CD) dispõe atualmente de 20 comissões permanentes $^{6}$, de caráter técnico-legislativo ou especializado, consideradas co-partícipes e agentes do processo legiferante, à medida que lhes cabe deliberar acerca das matérias submetidas ao seu exame ${ }^{7}$. A Resolução n. ${ }^{\circ}$ 17, de 1989, que dispõe sobre o Regimento Interno da Câmara dos Deputados (RICD), estabelece, em seu art. 24, inciso I, que, em razão da matéria inserida em seu campo temático, às comissões permanentes cabe discutir e votar todos os temas afetos ao Plenário da Casa que lhes sejam distribuídos, mas em caráter opinativo, não definitivo. Já o inciso II do mesmo artigo afirma que também cabe às comissões permanentes discutir e votar projetos de lei, dispensada a competência do Plenário, em caráter final, reservadas as exceções ${ }^{8}$. Assim como nas Constituições italiana e espanhola, e sob a justificativa de desconcentração do processo de elaboração legislativa, de participação mais efetiva dos parlamentares em caráter individual, de racionalização e de agilização dos trabalhos legislativos, a apreciação de projetos de lei isenta de exame por parte do Plenário da CD apresenta-se, sem dúvida, como uma das mais importantes competências dadas às comissões permanentes introduzidas em nosso ordenamento jurídico pela Carta Política de 1988.

Ressaltem-se, ainda, as demais competências das comissões permanentes, entre as quais figuram a realização de atividades de fiscalização por meio de instrumentos, tais como audiências públicas, convocações de ministros de estado, requerimentos de informação aos ministérios e às agências estatais, e solicitações de auditorias ao Tribunal de Contas da União (TCU), entre outros. Qualquer parlamentar pode-se valer de tais instrumentos, que se tornaram matéria constitucional em 1988; contudo, tal iniciativa, formalizada por meio da apresentação de requerimento, deve-se submeter à aprovação do colegiado competente ${ }^{9}$. Note-se o caráter informacional desses instrumentos, uma vez que agregam conhecimentos aos membros das comissões, promovendo a especialização, e reduzem incertezas na tomada de decisões.

\footnotetext{
5 "O intercâmbio opinião pública/Congresso/mídia tem relação causal de múltipla direção: mídia agenda Congresso / porque agenda povo / que agenda os mídia / que agenda Congresso / que agenda os mídia / que agenda povo" (Rodrigues, 2002. p 114).

${ }^{6}$ Além da Mesa Diretora.

${ }^{7}$ Art. 22, I, RICD.

${ }^{8}$ Arts. 24 , II, e $52, \S 6^{\circ}$, RICD.

9 O requerimento de informação também pode ser formulado fora do âmbito das comissões, por qualquer parlamentar, caso em que não se sujeita à deliberação delas.
} 
A audiência pública ${ }^{10}$ constitui instituto que visa à aproximação do cidadão com a casa legislativa (Santos; Nóbrega Netto e Carneiro, 2007. p. 169), em que se faz possível a reunião de representantes da sociedade organizada com os congressistas, com o fim de debater temática de interesse da população. Nesse sentido, são agendadas reuniões com vistas a colher subsídios para a instrução de matéria legislativa em tramitação, bem como tratar de assuntos de interesse público relevante por meio da propositura de requerimento de qualquer membro de comissão ou por solicitação de entidade interessada. Ao combinar funções de legislação e de fiscalização, a realização de audiência pública pode ocorrer tanto em meio à formulação de novas políticas públicas quanto no sentido de se revisarem políticas em curso, constituindo reunião especial em que especialistas ou pessoas diretamente relacionadas às questões submetidas ao debate discorrem sobre matéria específica. Às comissões permanentes se faculta ainda, em cumprimento ao princípio de freios e contrapesos entre os poderes do Estado, a convocação de ministro de estado ou de quaisquer titulares de órgãos diretamente subordinados à Presidência da República para prestar, pessoalmente, informações sobre assunto previamente determinado ${ }^{11}$. Outra importante atribuição conferida às comissões permanentes é o pedido escrito de informação a ministro de estado, cujo fim é a obtenção de informações relevantes por escrito, importando crime de responsabilidade a recusa ou o não atendimento, no prazo de 30 dias, bem com a prestação de informações falsas ${ }^{12}$.

Percebe-se quão relevantes são as atribuições conferidas às comissões permanentes, o que faz supor o prestígio imprimido à vida legislativa de cada uma delas. Todavia, em que pese a proposta de fortalecimento desses órgãos técnicos idealizada pelos constituintes de 1988, a afirmativa de que o processo de tomada de decisões na CD passa "ao largo" do sistema de comissões funda-se em trabalhos como os de Figueiredo e Limongi, entre outros. Considera-se que o RICD não prima pelo fortalecimento do referido sistema ao subtrair às comissões o total controle sobre suas decisões no que se refere à deliberação das matérias, em face da possibilidade de recurso de um décimo dos membros da Casa em sentido contrário ${ }^{13}$.

Outrossim, as comissões permanentes não detêm pleno domínio sobre os projetos que por elas tramitam, visto que estes, ainda que já se tenham submetido à deliberação, podem, em face dos requerimentos de urgência $^{14}$, ser revertidos ao plenário da Casa, o que retira das comissões a faculdade de dar início à apreciação das matérias ou renega o trabalho já empreendido por elas. Ao levar em consideração todas as implicações decorrentes das regras

\footnotetext{
${ }^{10}$ Arts. 58, §2 $2^{\circ}$ II; 255 e 256, RICD.

${ }_{11}$ Arts. 50, caput, e 58, §2 , III, CF/1988.

${ }^{12}$ Art. 50, $\$ 2^{\circ}, \mathrm{CF} / 1988$, e art. 116, RICD.

${ }^{13}$ Art. $132, \S 2^{\circ}$, RICD. Ressalte-se, porém, que a proposição recursal constitui, em tese, instrumento democrático instituído com vistas a resguardar o direito das minorias, no sentido de garantir a possibilidade de revisão das decisões tomadas em grau conclusivo no âmbito das Comissões Permanentes.

${ }^{14}$ Existem três modelos de urgência concernentes ao processo legislativo no âmbito da Câmara dos Deputados: a urgência prevista na Constituição, que pode ser solicitada unilateralmente pelo Presidente da República (Art. 164,
} 
institucionalizadas pelo RICD, o debate acerca das comissões permanentes da CD é quase unânime em considerar secundário o papel delas dentro do processo legislativo.

Atualmente, a composição das comissões permanentes varia entre 17 e 61 membros titulares ${ }^{15}$ e, regimentalmente, deve, tanto quanto possível, permitir a observância do princípio da proporcionalidade partidária, sendo que a distribuição das vagas entre os partidos ou blocos parlamentares, logo após a fixação da respectiva composição numérica, é organizada pela Mesa Diretora, integrada pelo Presidente da Casa e por dois Vice-Presidentes, além dos quatro Secretários. Esse importante órgão supervisiona os trabalhos legislativos e é responsável pela distribuição das vagas nas comissões permanentes ${ }^{16}$. As referidas vagas, registre-se, pertencem às bancadas partidárias e não aos parlamentares, do que se depreende que, em caso de desvinculação de deputado da respectiva legenda, devolve-se a vaga ao partido, a quem cabe a indicação de outro congressista para a ocupação do lugar. Uma vez definida, na primeira sessão legislativa de cada legislatura, a representação numérica dos partidos e blocos parlamentares nas comissões permanentes, confere-se aos líderes partidários a prerrogativa de indicação dos nomes dos membros das respectivas bancadas que, como titulares e suplentes, as integrarão. Feito isso, o Presidente da $\mathrm{CD}$ procede às respectivas designações e convoca as comissões para a eleição dos respectivos presidentes e vice-presidentes, definindo a data em que todos serão escolhidos ${ }^{17}$. Note-se o padrão altamente centralizado da organização institucional da CD que gira em torno de regras que distribuem direitos parlamentares de acordo com princípios partidários. Esse fato se revela uma variável explicativa absolutamente imprescindível à interpretação do comportamento legislativo na CME.

A mesa de comissão permanente é composta por um presidente e três vice-presidentes, eleitos por seus pares, com mandato até a posse dos novos componentes eleitos no ano subsequente, vedada a reeleição ${ }^{18}$. Sabe-se, contudo, pela praxe, que, anteriormente à realização da eleição, os componentes da mesa de cada comissão permanente são previamente escolhidos por acordo entre o Presidente da Casa e o Colégio de Líderes, integrado pelos líderes da Maioria, da Minoria, dos partidos, dos blocos parlamentares e do Governo ${ }^{19}$. No que respeita à eleição do presidente de comissão permanente, resta, pois, basicamente, a ratificação da escolha previamente realizada na referida reunião, ainda que se dê formalmente por meio de eleição, pelo voto dos membros da comissão indicados pelas lideranças partidárias ${ }^{20}$.

CF/1988); a urgência, em que a matéria é retirada da comissão e incluída na Ordem do Dia para apreciação pelo Plenário (Art. 151, RICD); e a urgência "urgentíssima" (Art. 155, RICD), que implica a votação imediata da matéria.

${ }^{15}$ Art. 25, §2 $2^{\circ}$ RICD.

${ }^{16}$ Arts. 14 e $\S \S ; 25, \S 1^{\circ}$, e 26, caput, RICD.

${ }_{18}^{17}$ Art. 28 , caput e $\$ 2^{\circ}$, RICD.

18 Art. 39, caput, RICD, com redação dada pela Resolução n. ${ }^{\circ}$ 20, de 2004. De acordo com o RICD, os vicepresidentes de comissão permanente devem, preferencialmente, ser filiados à mesma legenda partidária do presidente. ${ }^{19}$ Art. 20, §2 , RICD.

${ }^{20}$ O que não impede o aparecimento de candidaturas avulsas. 
Ao Presidente de comissão permanente compete definir a Ordem do Dia do órgão, isto é, proceder à escolha das matérias que serão votadas no decorrer das reuniões deliberativas; além de convocar e presidir todas as reuniões, sejam elas deliberativas ou de audiência pública; designar relatores e a eles distribuir as matérias sujeitas à apreciação; representar a comissão nas suas relações com a mesa da Casa, demais comissões, líderes e em relações externas à Casa, entre outras faculdades ${ }^{21}$. Considerando que aos Vice-Presidentes se permite substituir o Presidente da comissão tão-somente em seus impedimentos, sendo que, em caso de vacância do cargo de Presidente, procede-se a nova eleição ${ }^{22}$, o detentor do poder de agenda, no âmbito da comissão permanente, é, pois, o seu Presidente - aquele que define a Ordem do Dia do órgão, isto é, que escolhe as proposições que figurarão na pauta de votação, ainda que seja possível a inclusão de proposição na Ordem do Dia da comissão, para apreciação imediata, a requerimento de um terço de seus membros, aprovado pela maioria absoluta da respectiva composição plenária; ou que o autor da proposição requeira a inclusão dela na Ordem do Dia da reunião imediata, pendente de parecer, em caso de esgotamento de prazos ${ }^{23}$. Além disso, ao deter o poder de convocar as reuniões, mesmo que determinado requerimento de reunião de cunho informacional tenha, por exemplo, recebido a aprovação do colegiado, o objeto deste, isto é, a reunião requerida, somente se realizará, de fato, se o Presidente da comissão assim o determinar. Trata-se de um poder discricionário do Presidente da comissão, que somente agendará reuniões que bem lhe parecerem, não havendo absolutamente qualquer sanção ou recurso regimental, em específico, contra esse poder.

É importante acrescentar que, diferentemente do modelo norte-americano, não vigora nas comissões permanentes da CD o critério de antiguidade (seniority), visto que os cargos de presidente e de vice-presidente têm a duração média da sessão legislativa (um ano) ${ }^{24}$, vedada a reeleição. Isso repercute diretamente sobre o trabalho e a importância das comissões nas deliberações da $\mathrm{CD}$, já que sob a vigência do princípio da antiguidade eleva-se o estímulo à especialização dos membros no campo temático da respectiva comissão permanente, membros esses que passam à condição de interlocutores respeitados no processo legislativo, com poderes suficientes para resistir a pressões (Cintra e Bandeira, 2005. pp. 12-13).

\section{A dinâmica legislativa da CME}

A intensidade da atividade legiferante no âmbito das comissões permanentes da CD varia de órgão para órgão ${ }^{25}$. Por um lado, a Comissão de Constituição e Justiça e de Cidadania

\footnotetext{
${ }^{21}$ Art. 41, RICD.

${ }^{22}$ Salvo se faltarem menos de três meses para o término do mandato. Art. 40, caput e $\S$, RICD.

${ }^{23}$ Art. 52, $\S \S 4^{\circ} \mathrm{e} 5^{\circ}$, RICD.

${ }^{24} \mathrm{O}$ art. 39, RICD, estabelece que o mandato do Presidente e dos Vice-Presidentes das Comissões vigorará até à posse dos novos componentes eleitos no início do ano subsequente.

${ }^{25}$ No Parlamento italiano, por exemplo, algumas Comissões são mais ativas do que outras, tanto em relação a propostas analisadas quanto em relação ao tempo de tramitação (CAPANO e GIULIANI, 2001). Ribeiral acentua o
} 
(CCJC) é a recordista no recebimento de proposições, tendo em vista que o RICD confere ao órgão, no que respeita à constitucionalidade e à juridicidade da matéria, poder terminativo ${ }^{26} \mathrm{de}$ deliberação sobre todos os projetos tramitantes na Casa, o que implica a necessária tramitação de todo e qualquer projeto, à exceção daqueles que constituem objeto de apreciação por comissão especial ${ }^{27}$. Por outro lado, comissões como a de Desenvolvimento Urbano, a de Direitos Humanos e Minorias, a de Fiscalização Financeira e Controle e a de Turismo e Desporto, mais recentemente criadas, são as que menos recebem projetos.

Quadro n. 3 - Quantitativo de projetos e TVRs recebidos pelas Comissões Permanentes da CD entre $1 \% 1 / 2003$ e $31 / 12 / 2006$

\begin{tabular}{|c|c|c|c|c|c|}
\hline $\begin{array}{c}\text { Comissões Permanentes } \\
\text { da CD }\end{array}$ & 2003 & 2004 & 2005 & 2006 & Total \\
\hline $\begin{array}{l}\text { Comissão de Amazônia, Integração Nacional } \\
\text { e de Desenvolvimento Regional }\end{array}$ & 97 & 48 & 39 & 12 & 196 \\
\hline $\begin{array}{l}\text { Comissão de Agricultura, Pecuária, } \\
\text { Abastecimento e Desenvolvimento Rural }\end{array}$ & 118 & 70 & 92 & 60 & 340 \\
\hline $\begin{array}{l}\text { Comissão de Constituição e Justiça e de } \\
\text { Cidadania }\end{array}$ & 6767 & 2503 & 2513 & 1717 & 13500 \\
\hline $\begin{array}{l}\text { Comissão de Ciência e Tecnologia, } \\
\text { Comunicação e Informática }\end{array}$ & 547 & 375 & 616 & 557 & 2095 \\
\hline Comissão de Defesa do Consumidor & 457 & 245 & 138 & 67 & 907 \\
\hline $\begin{array}{l}\text { Comissão de Desenvolvimento Econômico, } \\
\text { Indústria e Comércio }\end{array}$ & 426 & 184 & 180 & 92 & 882 \\
\hline Comissão de Direitos Humanos e Minorias & 0 & 14 & 14 & 18 & 46 \\
\hline Comissão de Desenvolvimento Urbano & 79 & 44 & 38 & 30 & 191 \\
\hline Comissão de Educação e Cultura & 562 & 303 & 298 & 200 & 1363 \\
\hline $\begin{array}{l}\text { Comissão de Fiscalização Financeira e } \\
\text { Controle }\end{array}$ & 25 & 27 & 31 & 15 & 98 \\
\hline Comissão de Finanças e Tributação & 916 & 395 & 634 & 285 & 2230 \\
\hline Comissão de Legislação Participativa & 57 & 28 & 107 & 69 & 261 \\
\hline $\begin{array}{l}\text { Comissão de Meio Ambiente e } \\
\text { Desenvolvimento Sustentável }\end{array}$ & 0 & 127 & 66 & 80 & 273 \\
\hline Comissão de Minas e Energia & 75 & 59 & 34 & 35 & 203 \\
\hline $\begin{array}{l}\text { Comissão de Relações Exteriores e de Defesa } \\
\text { Nacional }\end{array}$ & 128 & 76 & 85 & 93 & 382 \\
\hline $\begin{array}{l}\text { Comissão de Segurança Pública e Combate } \\
\text { ao Crime Organizado }\end{array}$ & 148 & 101 & 101 & 94 & 444 \\
\hline Comissão de Seguridade Social e Família & 819 & 439 & 383 & 290 & 1931 \\
\hline $\begin{array}{l}\text { Comissão de Trabalho, de Administração e } \\
\text { Serviço Público }\end{array}$ & 830 & 391 & 404 & 325 & 1950 \\
\hline Comissão de Turismo e Desporto & 32 & 22 & 36 & 23 & 113 \\
\hline Comissão de Viação e Transportes & 314 & 159 & 153 & 111 & 737 \\
\hline
\end{tabular}

caráter diferenciado do sistema de comissões ao considerar que algumas seriam mais disputadas como arena política e consideradas mais relevantes para a condução do processo legislativo do que outras (Riberial, out./dez. 1998).

${ }^{26}$ A terminatividade implica que, caso não preencha satisfatoriamente os requisitos mínimos de constitucionalidade e de juridicidade, a proposição "terminará" sua tramitação legislativa ali mesmo na CCJC, sendo levada ao arquivo, ainda que primariamente sujeita à apreciação do plenário da Casa, salvo recurso de 1/10 dos membros da Casa (Art. 54, I, do RICD).

${ }^{27}$ Às comissões especiais, além do exame do mérito, cabe o da admissibilidade das matérias a elas submetidas. Isso significa que o exame da constitucionalidade e da juridicidade de matérias distribuídas aos órgãos em questão não se realiza no âmbito da CCJC (Art. 34 e 53, III e IV, do RICD). 


\begin{tabular}{l|rr|rrr}
\multicolumn{1}{c}{$\begin{array}{c}\text { Comissões Permanentes } \\
\text { da CD }\end{array}$} & $\mathbf{2 0 0 3}$ & $\mathbf{2 0 0 4}$ & $\mathbf{2 0 0 5}$ & $\mathbf{2 0 0 6}$ & Total \\
\hline Total & 12397 & 5610 & 5962 & 4173 & 28142 \\
Média 12 $^{\mathbf{2 8}}$ & 296,31 & 163,53 & 181,53 & 129,26 & 770,63 \\
Média 2 $^{\mathbf{2 9}}$ & 158,43 & 98,71 & 86 & 60 & 403,14 \\
\hline Fonte: Sileg - Demonstrativos Anuais dos Trabalhos das Comissões Permanentes - CCP & \multicolumn{3}{c}{}
\end{tabular}

Ao comparar os números obtidos com o cálculo da Média 1 com o número de projetos recebidos pela CME, ano a ano, constantes do Quadro n. ${ }^{\circ}$, percebe-se que o número de projetos recebidos pelo Órgão foi significativamente inferior à Média 1 no período. Considerando que uma análise da experiência de democracias consolidadas no processo legiferante leva à constatação de que os níveis de produção legislativa do Congresso brasileiro são muito elevados ${ }^{30}$, os dados aqui extraídos levam a crer que no período de 2003 a 2006 nem os parlamentares tomados individualmente, nem o Poder Executivo, principal legislador brasileiro na contemporaneidade, se interessaram pela propositura em número expressivo de projetos cuja matéria fosse afeta à CME e tramitasse pelas vias ordinárias ${ }^{31}$.

Ora, além da CME, as comissões permanentes da CD que eminentemente tratam de matérias relativas ao setor de infraestrutura - objeto de elevado interesse por parte do Poder Executivo, por seu cunho eminentemente econômico - são a Comissão de Agricultura, Pecuária, Abastecimento e Desenvolvimento Rural (CAPADR), a Comissão da Amazônia, Integração Nacional e de Desenvolvimento Regional (CAINDR), a Comissão de Ciência e Tecnologia, Comunicação e Informática (CCTCI), a Comissão de Desenvolvimento Econômico, Indústria e Comércio (CDEIC), a Comissão de Desenvolvimento Urbano (CDU), a Comissão de Meio Ambiente e Desenvolvimento Sustentável (CMADS) e a Comissão de Viação e Transportes (CVT). Considerando que a CCTCI tem por particularidade ser o fórum específico de deliberação de Atos do Poder Executivo de Concessão e Renovação de Concessão de Emissora

\footnotetext{
${ }^{28}$ A fórmula utilizada para o cálculo da Média 1, constante do Quadro n. ${ }^{\circ}$ 3, foi a seguinte: Média $1=(x-y): 19$ Média $1=$ Média de projetos recebidos pelas Comissões Permanentes no ano, excetuada a CCJC $^{28}$, por sua especificidade $x=n .^{\circ}$ de projetos recebidos pelas 20 Comissões Permanentes no ano $y=n .^{\circ}$ de projetos recebidos pela CCJC no ano.

${ }^{29}$ A fórmula utilizada para o cálculo da Média 2, constante do Quadro n. ${ }^{\text {3 }}$, foi a seguinte: Média $2=(x-y): 7$ Média $2=$ Média de projetos recebidos no ano pelas Comissões Permanentes que tratam de infraestrutura, excetuada a CCTCI ${ }^{29}$, por sua especificidade $x=n .^{\circ}$ de projetos recebidos pelas 8 Comissões Permanentes que tratam de Infraestrutura $y=n .^{\circ}$ de projetos recebidos pela CCTCI no ano.

${ }^{30} \mathrm{Em}$ 2004, a Casa dos Representantes norte-americana contabilizou um total de 1.732 projetos, ao passo que se originaram na Câmara de Deputados brasileira, naquele ano, nada menos que 2.496 proposições, fora as oriundas do Senado Federal, do Poder Judiciário, do TCU e do Poder Executivo. No total, foram apresentadas à CD 2.697 proposições legislativas naquele ano (Rodrigues, maio/2007. p. 11).

31 Por vias ordinárias, entendam-se as que incluem as Comissões Permanentes na tramitação legislativa das proposições, e por extraordinárias, as que culminam na criação de Comissão Especial, a da medida provisória, ou a que requeira urgência.
} 
de Rádio e Televisão (TVR) ${ }^{32}$, o que eleva em quantidade considerável o número de projetos a tramitar no órgão ${ }^{33}$.

Ao comparar, ano a ano, os números obtidos com o cálculo da Média 2 com o quantitativo de projetos recebidos pela CME, constantes do Quadro n. ${ }^{\circ} 3$, percebe-se que este foi pelo menos $40 \%$ inferior aos números apresentados pela Média 2 no período estudado. De fato, em média, das oito cmissões prmanentes que tratam de matéria relativa à infraestrutura, as únicas que receberam menos projetos que a CME, no período estudado, foram a CDU e a CAINDR $^{34}$.

Desses números, pode-se extrair que o Poder Executivo, detentor de primazia no processo legislativo, embora deposite grande interesse sobre a temática mineração e energia, utilizou seu poder de agenda em sentido negativo ao não se haver utilizado de suas faculdades para promover profusão legislativa que incluísse a CME no processo legislativo de proposições de seu interesse. Ademais, percebe-se que a quantidade de projetos despachados pela Presidência da Casa à CME foi significativamente inferior à média dos despachados às demais comissões prmanentes, a cada ano do período analisado. Isso leva a crer que, em princípio, a CME delibera menos sobre projetos, porque poucos são os projetos que por ela tramitam, comparativamente às demais cmissões permanentes.

A pesquisa, em face das restrições de seu porte, não prosseguiu no sentido de levantar o quantum das proposições que tramitaram na $\mathrm{CD}$, dentro do período analisado, cuja matéria tenha-se referido à energia ou à mineração, ou cujo rito de tramitação legislativa tenha tido ou não caráter conclusivo. Entretanto, pode-se acreditar que, se o Poder Executivo, por meio de seu poder de agenda, eximiu-se de incluir a CME no processo legislativo de temática por ele considerada prioritária, no período, provavelmente se valeu de outros instrumentos legislativos, que não projetos de lei (a medida provisória, por exemplo), ou de outros ritos de tramitação, que não o ordinário (a constituição de comissão especial ou o instituto da urgência, por exemplo), para promover políticas públicas nas áreas de mineração e de energia ${ }^{35}$.

Vale ressaltar que nem mesmo os parlamentares, individualmente, tiveram iniciativa de lei em número expressivo, cujo trâmite incluísse a CME em seu curso. Uma hipótese que poderia vir a explicar esta constatação seria a curta duração das carreiras parlamentares na $C D$, o que, segundo Amorim Neto e Santos (2003), afeta diretamente a capacidade de o Congresso

\footnotetext{
${ }^{32}$ Uma vez aprovadas no âmbito da CCTCI, as TVRs dão origem a projetos de decreto legislativo, de autoria do órgão, que versam sobre a outorga e a renovação da exploração de serviços de radiodifusão sonora e de sons e imagens.

33 Das 556 proposições legislativas recebidas pela CCTCI em 2006, 481 foram TVRs e Mensagens do Poder Executivo, tendo sido apenas 75 os projetos de lei recebidos pelo Órgão no período.

${ }^{34}$ Uma das razões de a CAINDR apresentar números pouco expressivos encontra-se no fato de que seu campo temático restringe-se a matérias especificamente relacionadas à Região Amazônica.

${ }^{35}$ Observe-se que os projetos de autoria do Poder Executivo seguem um rito de tramitação diverso dos de origem no Poder Legislativo, que tendem a tramitar ordinariamente, sem grande incidência de solicitações de urgência, como aqueles, e perpassando as comissões permanentes (Figueiredo e Limongi, 1999).
} 
Nacional aprovar leis de autoria própria. Pode ser que esse fato tenha interferido no interesse dos congressistas pela iniciativa de leis sobre a matéria em questão. Outra hipótese poderia ser o fato de que a participação do parlamentar no processo legislativo não influencia diretamente suas chances de reeleição (Pereira e Rennó, 2001). Note-se, porém, um fator imprescindível à análise: os congressistas têm apresentado projetos de lei preponderantemente de cunho social, ao contrário do Poder Executivo, cuja iniciativa de lei tem sido fundamentalmente econômicoadministrativa (Amorim Neto e Santos, 2003; Ricci, 2003). Além disso, há que considerar o advento do Programa de Aceleração do Crescimento - PAC, em 2007, e do futuro marco regulatório do setor de mineração, anteriormente previsto para 2009. O Poder Executivo pode haver excluído, deliberadamente, a CME como fórum hábil à discussão dos estudos por ele realizados no curso de toda a 52a Legislatura da CD (2003-2006) com vistas à formulação de políticas públicas de promoção do desenvolvimento dos setores de energia e de mineração. Desvendar o porquê de tais comportamentos pode vir a constituir objeto de análise posterior.

\begin{tabular}{|c|c|c|c|c|c|c|c|c|}
\hline \multirow{2}{*}{ CD } & \multicolumn{2}{|c|}{2003} & \multicolumn{2}{|c|}{2004} & \multicolumn{2}{|c|}{2005} & \multicolumn{2}{|c|}{2006} \\
\hline & Partido & $\begin{array}{c}\text { Cadeiras } \\
\text { em } \\
01 / 02 / 103\end{array}$ & Partido & $\begin{array}{c}\text { Cadeiras } \\
\text { em } \\
03 / 02 / 04\end{array}$ & Partido & $\begin{array}{c}\text { Cadeiras } \\
\text { em } \\
10 / 202 / 05\end{array}$ & Partido & $\begin{array}{c}\text { Cadeiras } \\
\text { em } \\
15 / 12 / 106\end{array}$ \\
\hline \multirow{13}{*}{$\begin{array}{l}\text { Coalizão } \\
\text { Governista }\end{array}$} & PT & 90 & PT & 91 & PT & 90 & PT & 82 \\
\hline & PMDB & 69 & PMDB & 78 & PMDB & 85 & PMDB & 81 \\
\hline & PPB & 43 & PTB & 51 & PP & 52 & PP & 51 \\
\hline & PTB & 41 & PP & 50 & PTB & 48 & PTB & 42 \\
\hline & PL & 33 & $\begin{array}{l}\text { Bloco } \\
\text { PL/PSL }\end{array}$ & 44 & $\begin{array}{c}\text { Bloco } \\
\text { PL/PSL }\end{array}$ & 47 & PL & 37 \\
\hline & PSB & 28 & PSB & 20 & PSB & 18 & PSB & 28 \\
\hline & PcdoB & 12 & PDT & 13 & PDT & 15 & PDT & 21 \\
\hline & PV & 6 & PcdoB & 9 & PcdoB & 9 & PcdoB & 11 \\
\hline & PMN & 2 & PSC & 7 & PV & 6 & PV & 7 \\
\hline & PSL & 1 & PV & 6 & PSC & 2 & PSC & 6 \\
\hline & PSC & 1 & - & - & - & - & PMR & 2 \\
\hline & - & - & - & - & - & - & PTC & 1 \\
\hline & TOTAL & 326 & TOTAL & 369 & TOTAL & 372 & TOTAL & 369 \\
\hline \multirow{5}{*}{$\begin{array}{l}\text { Oposição } \\
\text { ao Poder } \\
\text { Executivo }\end{array}$} & PFL & 75 & PFL & 67 & PFL & 61 & $\begin{array}{l}\text { PFL/ } \\
\text { PRONA }\end{array}$ & 67 \\
\hline & PSDB & 63 & PSDB & 51 & PSDB & 53 & PSDB & 55 \\
\hline & PPS & 21 & PPS & 20 & PPS & 22 & PPS & 15 \\
\hline & PDT & 17 & PRONA & 2 & PRONA & 2 & PSOL & 7 \\
\hline & PRONA & 6 & - & - & & - & - & - \\
\hline
\end{tabular}




\begin{tabular}{|c|c|c|c|c|c|c|c|c|}
\hline \multirow{2}{*}{ CD } & \multicolumn{2}{|c|}{2003} & \multicolumn{2}{c|}{2004} & \multicolumn{2}{c|}{2005} & \multicolumn{2}{c|}{2006} \\
\cline { 2 - 10 } & Partido & $\begin{array}{c}\text { Cadeiras } \\
\text { em } \\
\mathbf{0 1 / 0 2 / 0 3}\end{array}$ & Partido & $\begin{array}{c}\text { Cadeiras } \\
\text { em } \\
\mathbf{0 3 / 0 2 / 0 4}\end{array}$ & Partido & $\begin{array}{c}\text { Cadeiras } \\
\text { em } \\
\mathbf{1 0 / 0 2 / 0 5}\end{array}$ & Partido & $\begin{array}{c}\text { Cadeiras } \\
\text { em } \\
\mathbf{1 5 / 0 2 / 0 6}\end{array}$ \\
\hline & TOTAL & 182 & TOTAL & 140 & TOTAL & 138 & TOTAL & 144 \\
\hline
\end{tabular}

Fonte: COMPI/SGM e Liderança do Governo na CD.

Do exame do Quadro n. ${ }^{\circ}$ 4, verifica-se a ampla coalizão parlamentar arregimentada pelo Poder Executivo no período estudado, que lhe garantiu, em 2003, mais de 60\% das cadeiras da CD e, no período de 2004 a 2006, pelo menos 71,92\% delas, tendo chegado a 72,94\%, em 2005. Isso conferiu ao Presidente da República maioria parlamentar nas deliberações do Plenário e sugere decorrente preponderância do Chefe do Poder Executivo dentro do processo legislativo, levando-se em conta o elevado grau de disciplina partidária e a alta previsibilidade das votações (Limongi e Figueiredo, 1998. p. 24).

Quadro n. 5 - Presidentes da CME

\begin{tabular}{ccc} 
Sessão Legislativa & $\begin{array}{c}\text { Partido/UF do } \\
\text { Presidente da CME }\end{array}$ & $\begin{array}{c}\text { Posicionamento do Partido } \\
\text { em relação ao Poder Executivo }\end{array}$ \\
\hline $\mathbf{2 0 0 3}$ & PP/PR & Coalisão governista \\
$\mathbf{2 0 0 4}$ & PP/SC & Coalisão governista \\
$\mathbf{2 0 0 5}$ & PSDB/PA & Oposição \\
$\mathbf{2 0 0 6}$ & PSDB/GO & Oposição \\
\hline Fonte: Relatórios Anuais da CME e Liderança do Governo na CD.
\end{tabular}

A ciência da dimensão da coalizão governista verificada no período sugere, ainda, a existência, nos termos da Teoria Partidária, de um cartel legislativo comandado pelo Poder Executivo, em face do apoio dos líderes partidários em grau de maioria, no período analisado. Daí se conclui que a escolha do Presidente da CME sujeitou-se às preferências do Presidente da República tanto nos anos de 2003 e 2004, quando coube ao Partido Progressista (PP), partido integrante da coalizão formulada pelo Poder Executivo, quanto nos anos de 2005 e 2006, quando coube ao Partido da Social Democracia Brasileira (PSDB), partido de oposição, conforme o Quadro n. ${ }^{\circ}$.

Quadro n. ${ }^{\circ} 6$ - Presidentes da CD

\begin{tabular}{ccc}
\hline Sessão Legislativa & $\begin{array}{c}\text { Partido/UF do } \\
\text { Presidente da CD }\end{array}$ & $\begin{array}{c}\text { Posicionamento do Partido } \\
\text { em relação ao Poder Executivo }\end{array}$ \\
\hline $\mathbf{2 0 0 3}$ & PT/SP & Coalizão governista \\
$\mathbf{2 0 0 4}$ & PP/PE & Coalizão governista \\
$\mathbf{2 0 0 5}$ & PCdoB/AL & Coalizão governista \\
$\mathbf{2 0 0 6}$ & PCdoB/AL & Coalizão governista \\
\hline
\end{tabular}

Fonte: www.camara.gov.br e Liderança do Governo na CD. 
Quadro n. 7 - Lideranças que compuseram o Colégio de Líderes na CD

\begin{tabular}{|c|c|c|c|c|}
\hline \multirow{2}{*}{ Colégio de Líderes } & \multicolumn{4}{|c|}{ Ano/Partido } \\
\hline & 2003 & 2004 & 2005 & 2006 \\
\hline Liderança da Minoria & PFL & PFL & PFL & PFL \\
\hline Liderança do Governo ${ }^{36}$ & PCdoB & PDT/PT & PT & PT \\
\hline $\begin{array}{c}\text { Lideranças da coalizão } \\
\text { partidária do } \\
\text { Poder Executivo }\end{array}$ & $\begin{array}{l}\text { PT } \\
\text { PMDB } \\
\text { PPB } \\
\text { PTB } \\
\text { PL } \\
\text { PSB } \\
\text { PCdoB } \\
\text { PV } \\
\text { PMN } \\
\text { PSL } \\
\text { PSC }\end{array}$ & $\begin{array}{l}\text { PT PMDB } \\
\text { PTB } \\
\text { PP } \\
\text { PL } \\
\text { PSL } \\
\text { PSB } \\
\text { PDT } \\
\text { PCdoB } \\
\text { PSC } \\
\text { PV }\end{array}$ & $\begin{array}{l}\text { PT } \\
\text { PMDB } \\
\text { PP } \\
\text { PTB } \\
\text { PL } \\
\text { PSL } \\
\text { PSB } \\
\text { PDT } \\
\text { PCdoB } \\
\text { PV } \\
\text { PSC }\end{array}$ & $\begin{array}{l}\text { PT } \\
\text { PMDB } \\
\text { PP } \\
\text { PTB } \\
\text { PL } \\
\text { PSB } \\
\text { PDT } \\
\text { PCdoB } \\
\text { PV } \\
\text { PSC } \\
\text { PMR } \\
\text { PTC }\end{array}$ \\
\hline $\begin{array}{c}\text { Lideranças dos partidos } \\
\text { de oposição ao } \\
\text { Poder Executivo }\end{array}$ & $\begin{array}{l}\text { PFL } \\
\text { PSDB } \\
\text { PPS } \\
\text { PDT } \\
\text { PRONA }\end{array}$ & $\begin{array}{l}\text { PFL } \\
\text { PSDB } \\
\text { PPS } \\
\text { PRONA }\end{array}$ & $\begin{array}{l}\text { PFL } \\
\text { PSDB } \\
\text { PPS } \\
\text { PRONA }\end{array}$ & $\begin{array}{l}\text { PFL } \\
\text { PRONA } \\
\text { PSDB } \\
\text { PPS } \\
\text { PSOL }\end{array}$ \\
\hline
\end{tabular}

Fonte: COMPI/SGM.

Outrossim, há enorme probabilidade de o Poder Executivo haver preponderado no âmbito da CME, tendo, efetivamente, feito pleno uso de seu poder de agenda no órgão, uma vez que o preenchimento do cargo de presidente desse Colegiado submeteu-se à escolha e à indicação da liderança de seu partido, sujeita aos acordos firmados entre o Presidente da Casa que, de 2003 a 2006, integrou partido da coalizão de apoio ao Poder Executivo - e o Colégio de Líderes, cuja maioria compôs, no período, a referida coalizão, conforme os Quadros n. ${ }^{\circ}$ s 6 e 7.

Destarte, conclui-se que a CME deliberou preponderantemente sobre requerimentos e não sobre projetos de lei, entre 2003 e 2006, também em face do poder de agenda dos seus presidentes, que, ao haverem definido as pautas das reuniões, submeteram à discussão e à votação quantidade de requerimentos superior à de proposições legislativas. Resta inequívoca a ingerência das regras institucionais no comportamento dos atores políticos no âmbito da CME, nos termos propostos pelos neo-institucionalistas. De fato, isso faz delas variáveis independentes imprescindíveis à análise da vida legislativa do órgão, em razão de sua capacidade de constranger ou de motivar o comportamento dos sujeitos políticos e sua responsabilidade sobre resultados políticos obtidos na tomada de decisões.

Note-se, ainda, que a Teoria Partidária revela-se instrumental hábil a explicar o comportamento legislativo da CME, tendo em vista o evidente viés partidário nele verificado. Ademais, podem-se referendar os ditos de Limongi (1994. p. 29) acerca das comissões da Casa

${ }^{36}$ Nesse período, a Liderança do Governo assumiu as prerrogativas da Liderança na Maioria. 
dos Representantes norte-americana ao se perceber que fato semelhante se dá na $\mathrm{CD}$, uma vez que os poderes do Presidente da Casa e o dos Líderes partidários se revelam superiores aos das comissões permanentes. Ao que parece, a CME, por uma questão de antecipação, ajusta suas preferências e a tomada de decisões o mais próximo possível das preferências daqueles, antecipando a ação dos atores no próximo estágio do processo legislativo, semelhantemente ao que ocorre nas Comissões da Câmara Baixa dos EUA.

Quadro n. ${ }^{\circ} 8$ - Quantitativo de membros titulares e suplentes da CME

\begin{tabular}{|c|cc|c|cc|c}
\multirow{2}{*}{ Sessão Legislativa } & \multicolumn{2}{|c|}{$\begin{array}{c}\text { Membros da CME integrantes } \\
\text { da Coalizão Governista }\end{array}$} & \multicolumn{3}{|c}{$\begin{array}{c}\text { Membros da CME integrantes da } \\
\text { Oposição ao Governo }\end{array}$} \\
\cline { 2 - 7 } & Titulares Suplentes & Total & Titulares & Suplentes & Total \\
\hline $\mathbf{2 0 0 3}$ & 18 & 17 & 35 & 10 & 10 & 20 \\
$\mathbf{2 0 0 4}$ & 16 & 14 & 30 & 7 & 8 & 15 \\
$\mathbf{2 0 0 5}$ & 22 & 20 & 42 & 5 & 6 & 11 \\
$\mathbf{2 0 0 6}$ & 19 & 21 & 40 & 7 & 7 & 14 \\
\hline
\end{tabular}

Fonte: Relatórios Anuais da CME.

Além disso, pressupostos da Teoria Partidária adaptados à peculiaridade nacional são amplamente aplicáveis à CME, tendo em vista que a coalizão governista foi constituída, no período analisado, pela maioria dos partidos com representação não só na $\mathrm{CD}$ como na própria CME, e que este fato foi determinante para a atuação parlamentar no período. Ao se examinar o quantitativo partidário dos integrantes da CME, entre 2003 e 2006, constante do Quadro n. ${ }^{\circ}$, observa-se que o total de membros da coalizão governista foi superior em pelo menos $74 \%$ ao número de membros da oposição no período, tendo chegado a ser $185 \%$ mais elevado que este em 2006. Além disso, verifica-se que o número de membros-titulares integrantes da coalizão governista superou em pelo menos $80 \%$ o quantitativo da mesma categoria da oposição, tendo chegado a ser $166 \%$ mais elevado, em 2005. Percebe-se claramente que, em todo o período estudado, o número predominante de membros da CME pertenceu à coalizão partidária de apoio ao Presidente da República - o que leva a crer que as votações no âmbito do órgão, de 2003 a 2006, tenderam a cumprir os comandos dos líderes dos partidos governistas. Pode-se inferir, assim, que os membros da $\mathrm{CME}$, em grau de maioria, atenderam às preferências do Chefe do Poder Executivo ${ }^{37}$.

Ora, o requerimento de cunho informacional pressupõe a carência de conhecimento, de informação acerca de tema que não está bem esclarecido. É de esperar, então, que a autoria desse tipo de proposição seja, predominantemente, de integrantes da oposição ao Poder Executivo, visto que a assimetria de informações evidenciada entre as duas instâncias se verifica, entre outras razões, pelo fato de que o Poder Executivo não costuma compartilhar seus planos e metas, tampouco suas estratégias de implementação de políticas com seus opositores,

\footnotetext{
${ }^{37}$ Reserve-se especial atenção para os anos de 2005 e 2006, em que os presidentes da CME pertenciam ao PSDB, partido de oposição ao Presidente da República. Note-se que os referidos anos apresentaram numerário ostensivamente elevado de membros integrantes da ampla coalizão arregimentada pelo Poder Executivo.
} 
motivo pelo qual se supõe que os membros da CME contrários ao Governo ver-se-iam impelidos a utilizar instrumentos a eles regimentalmente conferidos, quais sejam, os requerimentos de cunho informacional, para extrair do Poder Executivo e de suas agências os esclarecimentos que julgassem necessários.

A grande quantidade de requerimentos informacionais apresentada no período, contraposta ao número pouco expressivo de membros da CME integrantes da oposição, faz crer que estes muito provavelmente tenham sido responsáveis pela autoria da parte predominante das proposições em análise, considerando que a incerteza acerca dos resultados das políticas adotadas é pressuposto fundamental da Teoria Informacional.

\begin{tabular}{|c|c|c|c|c|c|c|}
\hline \multirow{2}{*}{\multicolumn{2}{|c|}{$\begin{array}{l}\text { Partidos com representação na } \\
\text { CME/CD }\end{array}$}} & \multicolumn{5}{|c|}{$\begin{array}{l}\mathrm{N}^{\circ} \text { de Membros da CME que } \\
\text { apresentaram Requerimentos } \\
\text { Informacionais no Órgão }\end{array}$} \\
\hline & & 2003 & 2004 & 2005 & 2006 & TOTAL \\
\hline \multirow{12}{*}{$\begin{array}{l}\text { Partidos da } \\
\text { Coalizão } \\
\text { Governista }\end{array}$} & $\mathrm{PT}$ & 28 & 9 & 14 & 4 & 55 \\
\hline & PMDB & 6 & 6 & 4 & 0 & 16 \\
\hline & PP & 39 & 18 & 1 & 2 & 60 \\
\hline & РTB & 3 & 0 & 2 & 1 & 6 \\
\hline & PL/PR & 10 & 2 & 0 & 1 & 13 \\
\hline & PSL & 0 & 0 & 0 & 0 & 0 \\
\hline & PSB & 2 & 2 & 0 & 1 & 5 \\
\hline & PDT & 0 & 1 & 1 & 2 & 4 \\
\hline & PCdoB & 2 & 1 & 0 & 0 & 3 \\
\hline & PV & 0 & 0 & 0 & 0 & 0 \\
\hline & PSC & 0 & 0 & 1 & 0 & 1 \\
\hline & Sub-total & 90 & 39 & 23 & 11 & 163 \\
\hline \multirow{6}{*}{$\begin{array}{c}\text { Partidos da } \\
\text { Oposição ao } \\
\text { PE }\end{array}$} & PFL/DEM & 9 & 1 & 2 & 2 & 14 \\
\hline & PSDB & 11 & 22 & 7 & 9 & 49 \\
\hline & PPS & 0 & 0 & 2 & 0 & 2 \\
\hline & PRONA & 0 & 0 & 0 & 0 & 0 \\
\hline & PSOL & 0 & 0 & 0 & 0 & 0 \\
\hline & Subtotal & 20 & 23 & 11 & 11 & 65 \\
\hline
\end{tabular}

Entretanto, a partir do Quadro n..$^{\circ}$, mostra-se evidente que a autoria de requerimentos de cunho informacional, no período examinado, foi preponderantemente de deputados integrantes da coalizão partidária de apoio ao Poder Executivo. Esse fato não confirma o caráter informacional que os requerimentos analisados encerram, visto que, ainda que o Poder Executivo não tenha necessariamente disponibilizado simetricamente informações aos partidos que lhe conferem apoio legislativo, podendo ter guardado para si informações exclusivas e privilegiadas, é de supor que uma eventual assimetria tenha sido pontual.

Presume-se que os membros da coalizão se posicionaram, quanto às matérias atinentes à CME, conforme orientação do Poder Executivo, uma vez que a carência de redução de 
incertezas não constitui traço da coalizão governista, ainda que haja alegações de que as políticas regulatórias para o setor de infraestrutura não se tenham tornado manifestas, mediante discursos objetivos e articulados por parte do Poder Executivo, com o fim de balizar os atores públicos e privados, nem tenham apresentado objetivos explicitados, ao haver iniciado o ano de 2003 (Gaetani, 2003).

Quadro n. ${ }^{\circ} 10$ - Ministros do MME

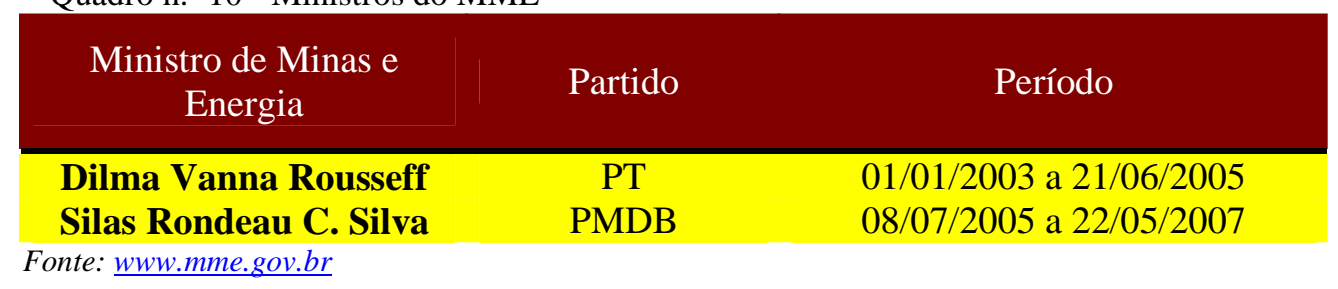

Observem-se, porém, as ponderações de Santos e Almeida (2005), na tentativa de responder à indagação de como a incerteza em torno da votação de matérias cruciais é reduzida. Os autores consideraram a "partidarização do Governo" resposta consistente com a experiência brasileira, isto é, a nomeação para o Ministério de agentes dos partidos que apoiam o Poder Executivo no Congresso Nacional, os quais, ao portar o controle formal da informação (no caso, a expertise da burocracia) e deter a iniciativa de fato sobre determinada área de políticas públicas, têm incentivo para tornar-se mais bem informados a respeito da relação entre políticas específicas e seus resultados. Ora, o Ministério de Minas e Energia (MME) teve sua titularidade ocupada por ministro indicado pelo partido do Presidente da República, o Partido dos Trabalhadores (PT), do início de 2003 à metade de 2005, e por ministro indicado pelo Partido do Movimento Democrático Brasileiro (PMDB), integrante da coalizão governista, a partir da metade de 2005, conforme observado no Quadro n. ${ }^{\circ} 10$.

Comparem-se, porém, os números constantes dos Quadros n. ${ }^{\circ} 9$ e 10. Nos anos de 2003 e de 2005, por exemplo, exatamente em período em que o partido do Presidente da República, o PT, titularizou o MME, os membros petistas da CME propuseram, isoladamente, mais requerimentos de cunho informacional do que todos os membros oposicionistas juntos. Isso não encontra lógica no seio da Teoria Informacional, sob cujo espectro espera-se que o desejo de especialização parta prioritariamente dos membros da oposição, no sentido de fazer frente à primazia legislativa do Poder Executivo decorrente da maioria que o apoia - o que, como se verifica, não ocorreu.

Santos e Almeida ponderam que os ministros brasileiros estão longe de ser agentes perfeitos dos parlamentares e que, diante de conflito de interesses entre o Poder Executivo e sua base parlamentar, aquele tem amplo incentivo para fazer uso estratégico da sua vantagem informacional em benefício próprio e em detrimento dos interesses dos parlamentares - razão pela qual estes buscariam colher benefícios, se não da produção, ao menos da coleta de informação alternativa à do Governo. 
Ora, é fato que o PT enfrentou, no período estudado, a resistência de alguns de seus deputados a muitas das políticas formuladas pelo Presidente da República. Entretanto, nenhum dos membros petistas da CME integrou o grupo dissidente do partido do Chefe do Poder Executivo. Não se pode desconsiderar, porém, que o PP, partido de 60 dos autores dos requerimentos, embora constitua um dos que sempre se posiciona ao lado do Poder Executivo, jamais contra, protagonizou episódio político histórico, em 2004, quando viu eleito Presidente da CD um membro seu, o então Deputado Severino Cavalcanti, por candidatura independente, em meio a desencontros entre a coalizão governista e o Poder Executivo. Sim, os pepistas membros da CME podem ter-se valido dos requerimentos informacionais para fins de especialização e de redução de incertezas.

No encalço de extrair o papel informacional dos requerimentos em questão, poder-se-ia pesquisar acerca da frequência dos membros da CME às reuniões objeto de tais requerimentos, que é registrada pela assinatura do congressista em lista própria, posteriormente documentada na ata descritiva de cada evento. Um registro de presença expressiva dos membros da CME em reuniões de audiência pública, por exemplo, levaria a crer que, de fato, a motivação para a propositura de requerimentos de cunho informacional pudesse ser, predominantemente, o desejo de especialização e de redução de incertezas. No entanto, não se procedeu à referida pesquisa em face da factualidade de que a simples aposição de assinatura do deputado em lista de presença não garante que este tenha tomado parte da reunião em questão ou que tenha permanecido nela por tempo relevante, visto que não há qualquer controle realizado nesse sentido. Há que considerar a não obrigatoriedade da presença do membro em reuniões dessa natureza, bem como a inexigência de quórum mínimo para a abertura dos trabalhos ou a sua consecução, ao contrário das reuniões deliberativas, que podem ser encerradas a qualquer tempo se verificada ausência de quórum mínimo para votação ${ }^{38}$.

Note-se que Santos e Almeida (2005) reputam a audiência pública como modalidade de reunião insuficiente, por si só, para a resolução do problema da ação coletiva enfrentado pelos parlamentares brasileiros na produção de informação. De acordo com os autores, o alto custo de oportunidade que o comparecimento a tais reuniões representa para o congressista constitui verdadeiro desincentivo ao emprego efetivo das audiências públicas, tendo em vista a agenda individual comumente sobrecarregada e também o esforço exigido para assimilação das informações por elas disponibilizadas. De fato, a sobrecarga de atividades do congressista dentro da CD dificulta a sua efetiva participação em muitas das atividades realizadas no âmbito das comissões permanentes. Diante da faculdade de se tornar membro titular de mais de uma

\footnotetext{
${ }^{38}$ Art. 50, RICD.
} 
comissão permanente e, ainda, suplente de outras", o parlamentar se "desdobra" para acompanhar reuniões que não raro se realizam em horários conflitantes. Além disso, há os trabalhos realizados pelas comissões especiais, pelas comissões parlamentares de inquérito, pelas frentes parlamentares e pelo próprio Plenário da Casa; sem contar reuniões como as de legenda, entre outras tantas a que o membro de comissão permanente ainda se vê comprometido a comparecer. Adicione-se a isso o atendimento, em gabinete, de prefeitos, de vereadores e de lobistas, entre outros integrantes de sua base eleitoral.

Destarte, vale, pois, considerar a questão sob um prisma paralelo. A resultante dos requerimentos, isto é, a informação, constitui bem coletivo, uma vez que é igualmente proporcionada a todos os membros da Comissão, seja por meio de exposições em discurso direto, em reuniões públicas, ou de documentação recebida por todos os integrantes da CME. Então, por que os membros da CME integrantes da coalizão governista buscariam informações por meio de tais instrumentos, no caso, os requerimentos informacionais, quando tais informações poderiam ser exclusivas suas, se obtidas por meios informais ${ }^{40}$ ? Ora, sob a ótica informacional, especialistas têm a tendência de não dividir todo o seu conhecimento com seus pares. Há consenso da literatura especializada acerca da ausência de incentivos para a aquisição e distribuição de informação no interior do Legislativo brasileiro (Santos e Almeida, 2005).

Ademais, a máxima informacional de que a redução de incertezas é um bem coletivo, tendo em vista o ideal de tomada de decisões com base na maior quantidade de informação possível, esbarra no paradigma partidário evidenciado pela maioria legislativa angariada pela coalizão governista. Independentemente do grau de especialização dos membros da CME, a tomada de decisões teve por norte as preferências do Poder Executivo, em face de seu poder de agenda e das prerrogativas regimentais conferidas ao Presidente da Casa, aos líderes partidários e ao Presidente da CME. Diante disso, é possível que, além de especialização e de redução de incertezas, haja outra motivação para a propositura dos requerimentos em questão.

Há que considerar, então, os pilares distribuitivistas para a interpretação a que a pesquisa se propôs, em uma adaptação à realidade brasileira do modelo apresentado por Mayhew quanto às motivações individuais dos parlamentares na Casa dos Representantes norteamericana. Em outras palavras, os membros da CME podem ter apresentado número significativo de requerimentos de cunho informacional como estratégia motivada por aspirações eleitorais, em razão, principalmente, da publicidade e do reconhecimento que a autoria de tais proposições confere ao parlamentar junto à respectiva base eleitoral (credit claiming, porkbarrel/casework, advertising e position taking).

\footnotetext{
${ }^{39}$ Existe a possibilidade de titularidade cumulativa na Comissão de Legislação Participativa e na Comissão de Segurança Pública e Combate ao Crime Organizado. Na condição de suplente, não há limitação para a participação de Deputado em Comissões Permanentes. Art. 26, §2º RICD. (Santos, Nóbrega Netto e Carneiro, 2007. p. 173).

${ }^{40}$ Figueiredo asseverou que os congressistas integrantes da coalizão governista dificilmente se valem de audiências públicas, por exemplo, por preferirem meios informais de comunicação com o Poder Executivo (Figueiredo, 2001).
} 
Entendam-se por regionais os requerimentos cujo objeto esteja diretamente relacionado à região e, principalmente, ao estado ou ao município do respectivo proponente; e por midiáticos os requerimentos que se tenham referido a notícias publicadas pelos mídia, em data recente $^{41}$, com citação expressa da fonte, ou, ainda que não tenha sido expressa, que se tenha remetido indiretamente a noticiário tornado público pelos mídia.

\begin{tabular}{c|c|c|cc|} 
Quadro $\mathrm{n}^{\circ} 11-$ Quantitativo de Requerimentos Informacionais de cunho regional e \\
apresentados na CME \\
$\begin{array}{c}\text { Requerimentos } \\
\text { Informacionais }\end{array}$ & 2003 & 2004 & 2005 & 2006 \\
\hline Total & 91 & 50 & 23 & 32 \\
Regionais & $47,25 \%$ & $56 \%$ & $47,83 \%$ & $21,87 \%$ \\
Mídiáticos & $75,82 \%$ & $66 \%$ & $65,22 \%$ & $62,5 \%$ \\
\hline Fonte: Sileg
\end{tabular}

Fonte: Sileg.

Do exame do Quadro n. ${ }^{\circ} 11$, é possível notar que não menos que $62,5 \%$ dos requerimentos tiveram caráter midiático, tendo chegado a 75,82\%, em 2003. Os requerimentos de caráter regional apresentados no período chegaram à marca de 56\%. Alguns pontos devem ser considerados para a análise desses dados. Primeiramente, vale lembrar o descrédito da classe política junto à opinião pública na contemporaneidade. Em face disso, o caráter regional dos requerimentos denota o interesse do parlamentar em apresentar respostas aos interesses de seu eleitorado e angariar, por consequência, o reconhecimento público, tendo em vista a reprodução eleitoral, seja no sentido da reeleição, seja com o fim de alçar postos no Poder Executivo.

Se o número de projetos de lei apresentados não interfere nas preferências do eleitor (Pereira e Rennó, 2001), a aparição do nome ou da imagem do parlamentar nos jornais, revistas, televisão ou rádios locais dão ao eleitorado a faculdade de considerar a atuação do congressista na Casa Legislativa e de conferir-lhe reconhecimento público e reprodução eleitoral almejada. Ademais, os requerimentos de caráter nacional, ou seja, que abordam temas de interesse não só da região do proponente, mas de toda a nação, encerram a faculdade de refletir uma proporção maior desse reconhecimento, o que cooperaria com as eventuais intenções de o parlamentar alçar postos no Poder Executivo em eleições subsequentes.

Outrossim, a simples propositura de requerimento midiático, tenha ele caráter regional ou nacional, é suficiente para chamar a atenção dos mídia, e, consequentemente, do eleitorado regional para o seu autor, independentemente de sua aprovação ou rejeição, ou, ainda, da efetiva realização de seu objeto. É certo que a realização de audiência pública sobre tema de caráter midiático, por exemplo, atrairá os holofotes para o autor da proposição e para a própria comissão, entretanto, o evento está sujeito ao poder de agenda do presidente do órgão, que

\footnotetext{
${ }^{41}$ Considere-se data recente uma semana anterior e uma posterior à data da propositura do requerimento.
} 
poderá simplesmente eximir-se de marcá-lo para data alguma, não tendo o autor do requerimento qualquer instrumento regimental que o obrigue a fazê-lo.

Isso, muitas das vezes, ocorre em face do excesso de requerimentos de conteúdos diversos, o que obriga o presidente do órgão a estabelecer prioridades que nem sempre correspondem às dos respectivos requerentes. Além disso, o presidente da comissão tem o poder discricionário de marcar a reunião para data que bem lhe parecer, que pode ser distante da data de ocorrência da notícia, o que importará na perda da oportunidade de reconhecimento público da iniciativa do requerente ao não despertar o interesse dos mídia pela realização do respectivo evento.

Sob esse aspecto, perceba-se que o requerimento de informação de caráter midiático chama a atenção dos mídia no momento de sua propositura, mas não necessariamente no momento da obtenção da informação. Isso se justifica pelo decurso do tempo. Os Ministérios e suas agências têm a faculdade de apresentar respostas aos referidos requerimentos em até 30 dias após o envio. Por esse tempo, na maioria das vezes, já ocorreu a perda de oportunidade midiática. A mesma afirmativa pode ser feita no que diz respeito aos demais requerimentos informacionais.

Os membros da CME podem ter persistido na apresentação de requerimentos de cunho informacional, apesar das particularidades expostas, justamente por que, quando a propositura do requerimento se dá imediatamente à ocorrência da notícia publicada pelos mídia, ainda que o seu objeto não se cumpra em tempo oportuno, tem a faculdade de atingir o seu primordial objetivo: publicidade e reconhecimento diante do respectivo eleitorado, visando à reprodução eleitoral.

Sob o espectro do modelo principal-agente, não se pode negar que a própria CME pode ter atuado como principal quando seus membros pretenderam especializar-se por meio da agregação de informações, com vistas à eventual redução de incertezas, considerando que alguns dos requerimentos propostos no período estudado podem haver pretendido alcançar tal objetivo. Resta claro, porém, que a motivação dos membros da CME não pretendeu à especialização, em plano primeiro. Os resultados da pesquisa levam a crer que, mais que especialização, os membros da CME buscaram cooperar com a reprodução eleitoral respectiva por meio da propositura de requerimentos de cunho informacional.

É certo que o poder de agenda do Presidente da República somado ao dos líderes partidários contrapõe-se aos efeitos individualistas e paroquialistas de incentivo eleitoral na Casa (Amorim Neto e Santos, 2002). O aspecto informacional revelou-se, porém, desmerecido, quando se verifica que tanto os partidos quanto os próprios membros da CME atuaram como principal: os partidos, em face do poder de agenda do Presidente da República, dos Presidentes da CD, das Lideranças, bem como dos Presidentes da CME; os membros da Comissão, em razão da conexão eleitoral verificada em sua atuação no âmbito da CME. No que se refere à 
propositura de requerimentos, as perspectivas distributivista e partidária se sobrepuseram à informacional (sem, contudo, haverem-na negado), especialmente diante da predominância de produção de caráter midiático e regional, o que torna evidente o selo individualista do comportamento dos membros da CME nesse particular.

\section{Considerações Finais}

O estudo da dinâmica das comissões do Congresso brasileiro ainda carece de pesquisa profunda, cujos resultados venham a se traduzir em canais de reflexão rumo à produção legislativa mais eficiente, eficaz e democrática, e à atuação parlamentar mais representativa e bem-sucedida. Não há dúvidas, pois, acerca da importância da reflexão provocada pela ciência da vida política congressual, à medida que venha representar instrumento profusor de transformações do status quo institucional político brasileiro, com vistas ao fortalecimento das instituições políticas e da efetiva representatividade democrática na produção legislativa, no âmbito do Poder cujo papel precípuo é o de criar leis.

Resta deixar consignado que a CME constitui fórum cuja legitimidade possui lastro constitucional e popular para a discussão e votação de matérias consideradas pedra de esquina da economia nacional. Excluir esta importante Comissão Permanente da CD da produção de legislação pertinente fere o propósito inicial do Constituinte de 1988, quando pretendeu o fortalecimento das comissões permanentes das casas legislativas.

Ora, se a força das comissões permanentes é considerada diretamente proporcional à da respectiva casa legislativa e à sua capacidade de interferência no processo de formulação de leis, na medida em que se lhes faculta imprimir uma perspectiva própria no seio da norma, qualquer alegação de fraqueza da base institucional desses órgãos no Brasil torna premente repensar o papel exercido não só pelas comissões, mas pelo próprio Legislativo na contemporaneidade. A pretensão original dos Constituintes de 1988 urge pela realidade fática na vida legislativa congressual brasileira, visto que comissões institucionalmente fortes tonificam a casa legislativa respectiva e reforçam a importância institucional do Poder Legislativo. O avigoramento do sistema de comissões importa, pois, tanto o fortalecimento do modelo representativo quanto o da democracia brasileira.

\section{Referências}

AMORIM NETO, O.; SANTOS, F. A produção legislativa do Congresso: entre a paróquia e a nação. Em: VIANNA, L. W. (org.). A democracia e os três poderes no Brasil. Belo Horizonte/Rio de Janeiro: UFMG/Iuperj, 2002. 559 p.

AMORIM NETO. O segredo ineficiente revisto: o que propõem e aprovam os deputados brasileiros. Em: Dados. n. 46, 2003. pp. 661-698.

CAPANO, G.; GIULIANI, M. Parlamento e processo legislativo in Itália. Bologna: Il Mulino, 2001. 
CINTRA, A. O.; BANDEIRA, R. M. G. O Poder Legislativo na organização política Brasileira. Consultoria Legislativa da Câmara dos Deputados, Estudo, Maio/2005.

CONSTITUIÇÃO da República Federativa do Brasil: 1988. 23 ed. Brasília: Câmara dos Deputados, Coordenação de Publicações, 2005. 437 p.

COX, G. W.; MCCUBBINS, M. D. Legislative leviathan: party government in the House. Berkeley: University of California Press, 1993. 324 p.

COX, G. W.; MCCUBBINS, M. D. "Bonding, structure, and the stability of political parties: party government in the House". Em: Legislative Studies Quarterly. n. 2, 1994. pp. 215-232.

FIGUEIREDO, A. C.; LIMONGI, F.. Executivo e Legislativo na nova ordem constitucional. 1 ed. Rio de Janeiro: Editora FGV, 1999. 232 p.

GAETANI, F. O Governo Lula e os desafios da política regulatória no setor de infra-estrutura. VIII Congreso Internacional del CLAD sobre la Reforma del Estado y de la Administración Pública, Panamá, oct./ 2003. pp. 28-31.

GILLIGAN, T.; KREHBIEL, K. "Collective decision-making and standing committees: an informational rationale for restrictive amendment procedures". Em: Journal of Law, Economics, and Organization. n. 3, 1987. pp. 287-335.

KREHBIEL, K. Information and legislative organization. Ann Arbor: University of Michigan Press, 1991. 314 p.

LIMONGI, F. O Novo institucionalismo e os estudos legislativos. A literatura norte-americana recente. Em: Bib. n. 37, $1^{\text {o }}$ semestre/1994. pp. 3-38.

LIMONGI, F.; FIGUEIREDO, A. Bases institucionais do presidencialismo de coalizão. Em: Lua Nova. v. 44:, 1998. pp. 81-106.

MAYHEW, D. R. Congress: the electoral connection. New Haven: Yale University Press, 1974.

McCOMBS, M.; SHAW, D. The emergence of american political issues: the agenda setting funtion of the press. [S.1.]: West Publishing, 1977.

PRATT, J. W.; ZECKHAUSER, R. Principals and Agents. Boston: Harvard Business School Press, 1991. pp. 37-51.

REGIMENTO Interno da Câmara dos Deputados: aprovado pela Resolução n. 17, de 1989, 7 ed. Brasília : Câmara dos Deputados, Coordenação de Publicações, 2006. 395 p.

RIBEIRAL, T. Comissão de Constituição e Justiça: uma ilha de institucionalização no Congresso Nacional. Em: Revista do Legislativo. n. 24, out./dez. 1998. pp. 66-82.

RICCI, Paolo. O conteúdo da produção legislativa brasileira: leis nacionais ou políticas paroquiais? Em: Dados. v. 46, n. 4, 2003. pp. 699 a 734.

RODRIGUES, M. R. Imprensa e Congresso ou como a mídia pauta a política. Brasília: Câmara dos Deputados, Coordenação de Publicações, 2002. 119 p.

RODRIGUES, R. J. P. Produção legislativa nas democracias consolidadas e a eficácia da atividade propositiva. Câmara dos Deputados, Consultoria Legislativa, Estudo, maio/2007.

SANTOS, F.; ALMEIDA, A. Teoria informacional e a seleção de relatores na Câmara dos Deputados. Em: Dados. v. 48, n. 4, 2005.

SANTOS, L. C. A.; NÓBREGA NETTO, M. G.; CARNEIRO, A. C. S. Curso de Regimento Interno da Câmara dos Deputados. 2. ed., ver., atual. e ampl. Brasília: Vestcon, 2007. 470 p.

SHEPSLE, K. A.; WEINGAST, B. "Institutional foundations of committee power". Em: American Political Science Review. n. 81, 1987. pp. 85-104.

WEINGAST, B.; MARSHALL, W. "The Industrial Organization of Congress". Em: Journal of Political Economy. n. 96, v. 1, 1988. pp. 132-163.

Artigo recebido em: 03/02/2010

Artigo aceito para publicação em: 25/03/2010 